\title{
Evaluation of postoperative gum chewing role in stimulating bowel motility in colonic surgery
}

\author{
Layth Q. AL-Harbawi ${ }^{a}$, Luay A. Hasan ${ }^{b}$ \\ ${ }^{a}$ Department of Surgery, College of Medicine, University of Mosul, ${ }^{b}$ Department of Surgery, Aljumhori Teaching Hospital, \\ Mosul, Iraq. Correspondence: Layth Q. AL-Harbawi. surgdep.mmc@yahoo.com. \\ (Ann Coll Med Mosul 2018; 40 (1): 60-63). \\ Received: $17^{\text {th }}$ Jun. 2012; Accepted: $13^{\text {th }}$ Nov. 2013.
}

\section{ABSTRACT}

Objective: Postoperative ileus (POI) after abdominal surgery is an inevitable consequence of various etiologies. It causes much discomfort to patients by resultant vomiting, abdominal distention, and prolonged hospital stay; thus, exploring efficient and cost effective solutions could reduce the patients' suffering and hospital stay. This study aimed to evaluate the effect of gum chewing on the duration of POI following colonic surgery.

Patients and methods: Ninety patients at Aljumhoory Teaching Hospital from October 2007 to October 2008 , undergoing elective large bowel surgeries were randomly assigned to the study group $(n=44)$ and the control group ( $n=46$ ). Patients in the study group chewed gum 3 times daily for 20 minutes starting from the $1^{\text {st }}$ postoperative day until the return of bowel function. The control group patients had standard postoperative treatment. All patients were assessed clinically and the data were collected using an inquiry forma for every patient.

Results: Study and control group patients were comparable at inclusion. The mean time for the passage of first flatus as well as the time for the first bowel movement was shorter significantly in the study group (by 20.4 hours, $P=<0.01$; by 22 hours, $P=<0.01$ ) respectively. The first feeling of hunger was also experienced earlier in study group cases (by 14.7 hours, $P=<0.01$ ). The postoperative hospital stay was shorter in the study group, but the difference was not significant $(\mathrm{P}=<0.1)$.

Conclusion: Early postoperative gum chewing significantly hastens the time of bowel function recovery following colonic surgery. Moreover, it is a cost-effective and well-tolerated treatment for POI.

Keywods: Postoperative colonic surgery, bowel motility, stimulation, evaluation,gum chewing.

\section{دراسة تقويمية لاور مضغ العلكة في تحفيز حركة الأمعاء بعد عمليات القولون الجراحية

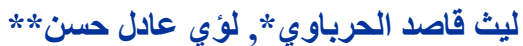 \\ *فرع الجراحة، كلية الطب، جامعة الموصل،*ثقسم الجراحةّ، مستشفى الجمهوري التعليم، الموصل، العراق}

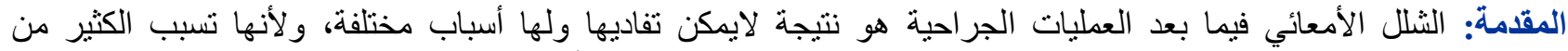

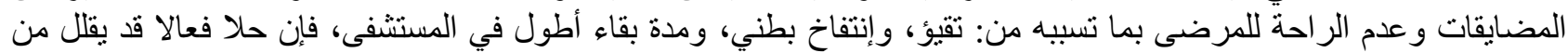
هذه التبعات

الهُف: تقييم فعالية ودور مضغ العلكة بعد العمليات الجر احية للقولون في تحفيز عملية رجوع الوظيفة للمعي مبكر ا.

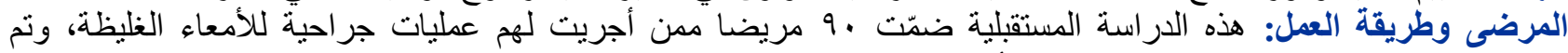

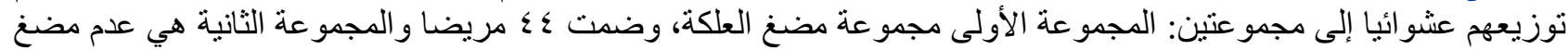

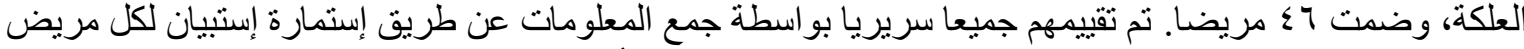

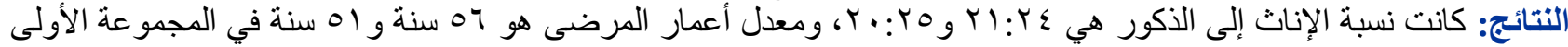

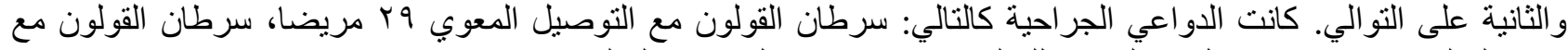

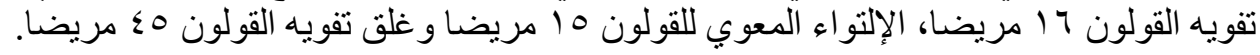




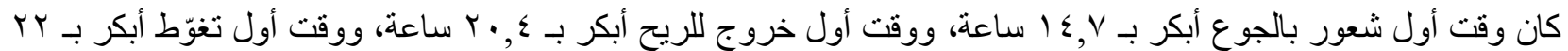

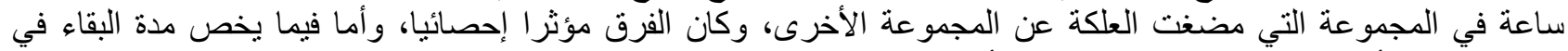

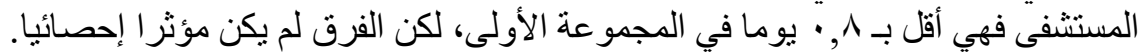

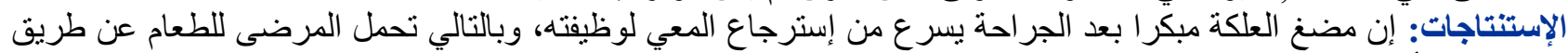

$$
\begin{aligned}
& \text { الفم بصورة أبكر. ألمان. } \\
& \text { الكلمات المفتاحيه: بعد العمليات الجر احيه للقولون، حركة الأمعاء، تحفيز ، تقييم، مضغ العلكه. }
\end{aligned}
$$

\section{INTRODUCTION}

ost operative ileus (POI) is a transient cessation of coordinated bowel motility after surgical intervention, which prevents effective transit of intestinal contents and/or tolerance of oral intake. ${ }^{1}$ Primary POI occurs in the absence of any precipitating complication, ${ }^{2}$ it is an inevitable response to surgical trauma. ${ }^{1}$ Secondary $\mathrm{POI}$ occurs in the presence of a precipitating complications such as uremia and hypokalemia. ${ }^{3}$

The incidences of $\mathrm{POI}$ in different common abdominal surgeries are; $4.1 \%$ after abdominal hysterectomy, $6.2 \%$ after appendectomy, $14.9 \%$ after large bowel resection and $19.2 \%$ after small bowel resection. ${ }^{4}$ The average time for resolution of $\mathrm{POI}$ after major abdominal surgery is 24 hours for small bowel surgery, 24- 48 hours for stomach surgery, and 48-120 hours for large bowl surgery. ${ }^{5}$

The manifestations and consequences of postoperative ileus include; delayed passage of flatus and stool, increased nausea and vomiting, delay in resuming oral intake with possible need for parenteral nutrition and wound healing, and delay in postoperative mobilization. In addition, $\mathrm{POI}$ increases the risk of other complications such as pulmonary complications. Prolonged hospitalization decreases patient satisfaction and increases health care cost. ${ }^{6,7}$

Conventionally, POI has been managed by gastric decompression by nasogastric (NG) tube, keeping the patient nil per mouth, and intravenous fluid supplementation until the ileus resolves and patient passes flatus. ${ }^{8}$ However, very few improvements in the understanding of $\mathrm{POI}$ have been established in the past 100 years, and therefore therapies have changed minimally. In recent years, the use of gum chewing has emerged as a new and simple modality for decreasing POI. Chewing gum acts as sham feeding, potentially stimulating gastric and bowel motility through repetitive stimulation of the cephalic-vagal complex. ${ }^{9}$ Recently, it has been proposed that hexitols present in sugarless chewing gums might also be playing a role in the amelioration of POI. ${ }^{4}$

The aim of this study was to assess the efficacy of the gum chewing after abdominal surgery especially in the return of bowel function.

\section{PATIENTS AND METHODS}

This is a prospective randomized study, included 90 patients with colonic surgeries, between October 2007 and October 2008 in the surgical ward of Al- Jumhoory Teaching Hospital. The surveyed patients were evaluated for the effectiveness of the sugarless gum chewing in alleviation of postoperative ileus following abdominal surgeries, especially involving the large bowel. The surgical operations included colon cancer (resection and anastamosis), volvulous of sigmoid, colon cancer (resection and colostomy), and closure colostomy.

The patients were divided into two groups:

Group 1: gum chewing (44) patients (24 males and 20 females).

Group 2: no gum chewing (46) patients (25 males and 21 females).

Mean age for group 1 was 56 years, and for group 2 was 51 years.

The gum chewing group started chewing sugarless gum (1 GM per stick) that does not contain hexitol, in the morning of the first postoperative day. Patients chewed one stick of gum three times daily: in the morning, afternoon and in the evening, for 20 minutes.

Postoperative analgesia (diclofenac sodium and tramadol injections) was given to all patients in both groups ( $75 \mathrm{mg} \& 50 \mathrm{mg}$ twice daily) respectively tailored to the individual patients requirement.

The two groups were tested for:

1. Time at first flatus. 
2. Time at first feeling of hunger.

3. Time at first bowel motion.

4. Duration of hospital stay.

Student-t test was used to perform statistical analysis where $\mathrm{P}<0.05$ was considered statistically significant for all compared values.

\section{RESULTS}

All patients (90) of the two groups completed the protocol study until recovery of bowel. There were no difference in mean age and gender (the female: male ratio was $(1: 1.25)$ (No. $21: 25)$ in the no gum group and (1:1.4) (No. 20:24) in the gum chewing group. Table 1 showing all 90 patients with different surgeries, classified according to gender.

Table 2 showing mean time of duration of surgery and operative complication in all 90 patients.

All patients in the two groups started mobilization on the first postoperative day.

Table 3 showing different clinical characteristic in both group (gum chewing and control).

A part from three patients in the control group and one patient in the study group who had mild chest infections, there were no other complications.

Table 1. Types of colonic surgery used in the study \& no. of patients in both groups according to sex.

\begin{tabular}{|c|c|c|c|c|}
\hline \multirow{2}{*}{$\begin{array}{l}\text { Indication for } \\
\text { surgery }\end{array}$} & \multicolumn{2}{|c|}{ Control group } & \multicolumn{2}{|c|}{$\begin{array}{c}\text { Gum chewing } \\
\text { group }\end{array}$} \\
\hline & Male & Female & Male & Female \\
\hline $\begin{array}{l}\text { Colon cancer } \\
\text { (resection \& } \\
\text { anastamosis) }\end{array}$ & 8 & 6 & 8 & 7 \\
\hline $\begin{array}{l}\text { Volvulous of } \\
\text { sigmoid }\end{array}$ & 3 & 2 & 3 & 2 \\
\hline $\begin{array}{l}\text { Colon cancer } \\
\text { (resection \& } \\
\text { colostomy) }\end{array}$ & 3 & 5 & 3 & 4 \\
\hline $\begin{array}{l}\text { Closure } \\
\text { colostomy }\end{array}$ & 11 & 8 & 10 & 7 \\
\hline Total & 25 & 21 & 24 & 20 \\
\hline
\end{tabular}

Table 2. Intraoperative findings.

\begin{tabular}{lccc}
\hline \multicolumn{1}{c}{ Characteristics } & $\begin{array}{c}\text { Control } \\
\text { group } \\
\text { (n 46) }\end{array}$ & $\begin{array}{c}\text { Gum } \\
\text { chewing } \\
\text { group } \\
\text { (n 44) }\end{array}$ & $\begin{array}{c}\text { P- } \\
\text { Value }\end{array}$ \\
\hline $\begin{array}{l}\text { Mean (SD) duration } \\
\text { of surgery in } \\
\text { minutes }\end{array}$ & $115(50)$ & $108(39)$ & 0.02 \\
$\begin{array}{l}\text { Intra operative } \\
\text { complications }\end{array}$ & 0 & 0 & 0 \\
\hline
\end{tabular}

Table 3. The main outcome measures.

\begin{tabular}{lccc}
\hline \multicolumn{1}{c}{ Characteristics } & $\begin{array}{c}\text { Gum } \\
\text { Chewing } \\
\text { group } \\
(\mathbf{n}=44)\end{array}$ & $\begin{array}{c}\text { Control } \\
\text { group } \\
(\mathbf{n}=46)\end{array}$ & $\begin{array}{c}\mathbf{p} \text { - } \\
\text { value }\end{array}$ \\
\hline $\begin{array}{l}\text { Time for } 1^{\text {st }} \text { bowel } \\
\text { motion mean (SD) } \\
\text { hr }\end{array}$ & $52.6(9.1)$ & $74.6(6.8)$ & $<0.01$ \\
$\begin{array}{l}\text { Time for 1 } 1^{\text {st }} \text { feel of } \\
\text { hunger mean (SD) } \\
\text { hr }\end{array}$ & $48.9(7.6)$ & $63.6(8.0)$ & $<0.01$ \\
$\begin{array}{l}\text { Time for 1 } 1^{\text {st }} \text { flatus } \\
\text { mean (SD) hr }\end{array}$ & $53.3(8.0)$ & $73.7(6.5)$ & $<0.01$ \\
$\begin{array}{l}\text { Post-operative } \\
\text { stay in hospital } \\
\text { mean (SD) days }\end{array}$ & $5.0(2.7)$ & $5.8(2.6)$ & 0.1 \\
\hline
\end{tabular}

\section{DISCUSSION}

There was significant reduction in mean time for the first feeling of hunger postoperatively in the gum chewing group, (39) patients which was in the second postoperative day, while 30 patients in the control group experienced it in the third postoperative day (14.7 hours; $P$ value $=<0.01$ ). This is similar to Asao et al study. ${ }^{10}$ in which the time was (1.1day, $p$ value $=<0.01$ ), but not to Rob Schuster et al study. ${ }^{11}$ who found no significant difference in time for feeling of hunger between both groups ( 9.3 hours; $P$ value $=0.27$ ).

There was significant decrease in mean time for first passage of flatus in gum chewing group (20.4 hours; $P$ value $<0.01$ ). This result is comparable to Asao et al, ${ }^{10}$ Schuster et al, ${ }^{11}$ Chan et al, ${ }^{12}$ Vasquez et $a l^{13}$ and Kouba et al; ${ }^{14}$ their results were: (1.1 days; $\mathrm{p}<0.01)$, (14.8 hours; $\mathrm{P}<0.05)$, (20.8 hours; $P<0.0006)$ and (14 hours) and $(0.5$ day; $p<0.001)$ respectively. On the other hand, Matros et $a l^{15}$ finding was ( 7 hours; $P=0.384$ ), this may be attributed to how the gum was given, since they used the gum in combination with sips of clear fluid.

In our study there was a statistically significant shorter mean time for first bowel movement in gum chewing group $(22$ hours; $P<0.01)$. Similarly Schuster et $\mathrm{al}^{11}$ (26.2; $\left.\mathrm{P}=0.04\right)$, Chan et al ${ }^{12}$ (33.3 hours; $P<0.0002$ ), Vasquez et al 25 (25 hours), ${ }^{13}$ and Kouba et al ${ }^{14} 26$ (0.7 day; $\left.p<0.01\right)$ reported comparable results. However, our outcome is different from that of Quah et $a{ }^{16}$ ( 0.6 days) and Matros et $a l^{15}$ in which there was no significant reduction in mean time for bowel motion. 
From our data we found that there was statistically non-significant reduction in mean time for postoperative hospital stay (0.8 day; $P$ value $=0.1$ ) Table 3. These results are consistent with those obtained in studies performed by Quah et al (1.71 days),$^{16}$ De Castro et al (1.3 day) ${ }^{17}$ and a meta-analysis done by Purkayastha et al (3.27; $\mathrm{P}=0.23),{ }^{18}$ but not with that of Asao et $a l^{10}$ which may be attributed to the use of laparoscopic colectomy in their study.

\section{CONCLUSION}

Gum chewing early in the postoperative period following colonic abdominal surgery significantly hastens time to bowel function and ability to tolerate feeding.

\section{REFERENCES}

1. Luckey A, Livengston $E$, Taché $Y$. Mechanisms and treatment of postoperative ileus. Arch Surg 2003; 138(2): 206-14.

2. Sarna SK. Cyclic motor activity; migrating motor complex. Gastroenterology 1985; 89(4): 894-913.

3. Sanjay M, Sham S, Pradeep T. Role of Gum Chewing on the Duration of Postoperative lleus Following lleostomy Closure Done for Typhoid Ileal Perforation: A Prospective Randomized Trial. Saudi J Gastroenterol 2012; 18(2): 111-117.

4. Delaney CP, Wolff BG. Postoperative ileus following bowel resection. ther. Clin risk manag 2008; 4(5): 913917.

5. Livingston EH, Passaro EP. Postoperative ileus. Dig Dis Sci 1990; 35(1): 121-31.

6. Taché $\mathrm{Y}$, Monnikes H, Bonaz B, Rivier J. Role of CRF in stress-related alterations of gastric and colonic motor function. Ann N Y Acad Sci 1993; 697: 233-43.

7. Kalff JC, Wolfgang HS, Simmons RL, Bauer AJ. Surgical manipulation of the gut elicits an intestinal muscularis inflammatory response resulting in postsurgical ileus. Ann Surg 1998; 228(5): 652-663.
8. Borody TJ, Quigley EM, Phillips SF, et al. Effects of morphine and atropine on motility and transit in the human ileum. Gastroenterology 1985; 89(3): 562-70.

9. Hocevar BJ, Robinson B, Gray M. Does chewing gum shorten the duration of postoperative ileus in patients undergoing abdominal surgery and creation of a stoma? J Wound Ostomy Continence Nurs 2010; 37(2): 140-6.

10. Asao T, Kuwano H, Nakamura J, Morinaga N, Hirayama I, Ida M. Gum chewing enhances early recovery from postoperative ileus after laparoscopic colectomy. J Am Coll Surg 2002; 195(1): 30-2.

11. Schuster R, Grewal N, Greaney GC, Waxman K. Gum chewing reduces ileus after open sigmoid colostomy. Arch Surg 2006; 141(2): 174-6.

12. Chan MK, Law WL. Use of chewing gum in reducing postoperative ileus after elective colorectal resection: a systematic review. Diseases of the Colon and Rectum 2007; 50(12): 2149-57.

13. Vásquez W, Hernández AV, Garcia-Sabrido JL. Is gum chewing useful for ileus after elective colorectal surgery? A systematic review and meta-analysis of randomized clinical trials. J Gastrointest Surg 2009; 13(4): 649-56.

14. Kouba EJ, Wallen EM, Pruthi RS. Gum chewing stimulates bowel motility in patients undergoing radical cystectomy with urinary diversion. Urology 2007; 70 (6): 1053-56.

15. Matros E, Rocha F, Zinner $M$, et al. Does gum chewing ameliorate postoperative ileus? Results of a prospective, randomized, placebo-controlled trial. J Am Coll Surg 2006; 202(5): 773-8.

16. Quah HM, Samad A, Neathey AJ, Hay DJ and Maw A. Does gum chewing reduce postoperative ileus following open colectomy for left-sided colon and rectal cancer? - a prospective randomized controlled trial. Colorectal Disease 2005; 8(1): 64-70.

17. D Castroa SM, van den Esschertb JW, van Heeka NT, et al. A systematic review of the efficacy of gum chewing for the amelioration of postoperative ileus. Dig Surg 2008; 25(1): 39-45

18. Purkayastha S, Tilney HS, Darzi AW, Tekkis PP. Meta-analysis of randomized studies evaluating chewing gum to enhance postoperative recovery following colectomy. Arch Surg 2008; 143(8): 788-93. 